\title{
Coastal zones along the Adriatic Sea: Italian and cross-border experiences
}

\author{
D. Cialdea \\ L.A.Co.S.T.A. Laboratory, D.I.B.T. Department, \\ University of Molise, Italy
}

\begin{abstract}
In the panorama of Planning Policies in Cross-Border States along the Adriatic Sea, the analysis of different territorial realities makes it clear that the coastline is a "critical zone" for town and country planning. The fragmentation of coastal areas, caused by residential constructions often unrelated to planning policies, generates a lot of areas that need to be reorganized. This paper aims to illustrate the results of international comparative studies in planning coastal areas, undertaken in the L.A.Co.S.T.A. Laboratory of the University of Molise. This work involves a comparative analysis of urban and territorial planning processes in force in Italy, Albania and Croatia. Italian processes aim to unify the concepts of "urban" and "landscape" that traditionally followed different planning and legislative schemes. In the Balkan States, the planning processes derive from a historical and political context profoundly marked by events from 1991 to today. The main laws of land-use planning were drawn up after 1991, ex novo or as replacements for existing ones, proposing a totally different system from the previous one, where existing.
\end{abstract}

Keywords: landscape, planning, waterfront.

\section{Introduction}

The work undertaken by the L.A.Co.S.T.A. Laboratory has examined the historical evolution of the laws and norms relating to landscape protection in each examined country, with particular attention to those preserving the landscape values in harmony with the territorial plans, to contrast the growing anthropic development especially along the coastal zones.

As a continuation of what has already been drawn up by L.A.Co.S.T.A. in recent years, our research has expanded work on the systems on which the 
territorial planning of the Balkan countries is based, in order to provide useful contributions about "measures for the protection of landscape values".

The study wanted to take a close look at aspects of planning in coastal areas that are particularly interesting from an environmental point of view.

For Croatia we analyzed the area of the Neretva River Delta, south of Split, and for Albania, the area of the Karavasta Lagoon, south of the port of Durres.

We have chosen these two cross-border areas as they have several aspects in common: both are areas included in the Ramsar Convention List, both are coastal areas and, in particular, both are situated in an agricultural productive context.

We aimed to analyze these sites, because of their naturalistic importance and also because of the attention paid to planning tools to support their protection. Moreover, the conditions of the coastal area in the Molise Region are different: it has numerous natural areas classified as Sites of Community Importance - which are located along the mouths of major rivers and along the coast and where there are residual sand dunes - but there are no Ramsar areas. They are also inserted in a typically agricultural context, for which specific planning norms are totally lacking.

\section{The approach to planning activities in coastal areas}

The approach to planning activities is very different in Italy and in the crossborder countries.

The long Italian tradition of urban planning has defined, from the 1940s onwards, well-differentiated levels of planning - in particular, by giving strength to planning above municipality level.

In the Balkan States, 1991 can be seen as a turning point in the history of these countries: in that year, Croatia declared its independence from the Federation, while in Albania, Parliamentary Democracy replaced the Socialist Government of Enver Hoxha.

The Italian planning system began in a historical and temporal context that is very different from that of Croatia and Albania, and is the result of a stratification of plans and regulations from the 1940s to today.

After the cultural ferment and the evolution of the urban sector in the 1970s, in Italy there was a progressive slowdown due to the lack of control on the development of the territory from the Central Government and subsequently from the frequent inefficiency of the Regional Authorities. During the nineties in Italy many competences in urban planning matters were transferred to the Provinces, following the general trend of delegating administrative functions to Local Authorities. Also in Croatia and in Albania, in parallel to the consolidation of the Republic, the decentralization of administrative functions from Central Government to Local Government Units occurred with the consequent delegation of planning activities.

The first laws for land-use planning were therefore drawn up after 1991, ex novo or replaced existing ones, proposing a system totally different from the previous one [1-6]. 
The territorial analysis conducted on the countries in the case studies reveals that the increasing anthropic use mostly concerns coastal areas, leaving almost or entirely unchanged the inland areas, with the exception of the areas of the capital, Zagreb, or Tirana.

As a result of this non-regulated urban development suffered by the two Balkan countries, their spatial planning systems, both delayed with respect to the strong anthropogenic pressure present along the Adriatic coastal areas, should deal with the increasing development within the territory, trying to shorten as much as possible the time necessary for the implementation of these plans. This need is even more evident in Albania, where the processes of formation and implementation of plans are often very long, thus contributing to the extension of the phenomena of illegal building.

Both Croatia and Albania are areas rich in environmental values. In particular, in Croatia the numerous islands that characterize the country form an environmental patrimony of considerable importance, safeguarded through the instrument of protected areas and through the implementation of the Nature 2000 Network. There are also sites of international interest such as Ramsar areas and a MAB Reserve.

The Albanian coasts are, despite the rapid building development, still rich in uncontaminated naturalistic values between beaches and lagoons that outline a very articulated coast.

Even along the Albanian coast there are numerous Ramsar areas and the Government is taking steps towards drafting a list of areas for inclusion in the Nature 2000 Network.

\section{Natural features on national and cross-border coasts}

The examined coastal areas overlooking the Adriatic Sea are very deeply characterized by special features. Both coasts develop in parallel on a NorthWest/South-East alignment.

As regards the geological characteristics on both sides there are soils of the same age although the more recent land typical of the Italian coastline, is totally missing on the Balkan coasts. This difference creates totally different geographical features along the two coast lines.

The western coast is mainly linear and flat with sandy beaches, with the exception of some promontories.

This geographical shape is defined by the land's geology, which is mostly clay deposits and sandstones, and by the presence of surface runoff that brings sediment and detritus material along the coast. The eastern coast, in the section between the Gulf of Trieste and the border between Montenegro and Albania, on the other hand, is characterized by a very indented coastline flanked by numerous islands that run parallel to the coast [7-11].

This shape is defined by the mainly karstic nature of the coastal region, where, for several hundred kilometers, there are rivers carrying alluvial sediment to the coast. 
Finally, on the Albanian coast, flat shapes return, coastlines of floodplains and lagoons.

The Croatian coasts along the Adriatic Sea, therefore, constitute a rich environmental heritage, within a complex system of protected areas: they have a jagged outline, with twelve hundred islands, islets and rocks and with important contexts, such as the archipelago of Kornati (Dugi Otok), Mljet (Mljet), the Brijuni (Brioni) and the waterfalls of the Krka.

Croatia became a part of the European Union in July 2013 and, therefore, the Government begun to align to European Directives for environmental protection. The final list of Nature 2000 Network sites is in the process of being adopted by the Croatian Government. The list will be sent to the European Commission together with the standard forms and maps. It is expected that the final list will contain more than 700 SCI proposals (174 of which will be caves) and 38 SPAS [12], thus putting Croatia, together with Slovenia and Bulgaria, on top of the standings among the countries with highest percentages of territory included in the Nature 2000 Network. Practically the whole of the coastline and the islands are being inserted within the Nature 2000 Network.

In addition, Albania is characterized by a rich biodiversity and a wide presence of ecosystems, which are untouched or only slightly affected by anthropic activity [13-14]. The Law no. 8906/2002 on protected areas [15] incorporated from previous initiatives many indications, regarding the protection and enhancement of natural resources.

In fact, the object of the law is "the conservation, administration, management and use of protected areas and their natural and biological resources". The final goal is to "facilitate the conditions for the development of environmental tourism, information and education of the citizens, the direct or indirect financial gain in favor of the local people, the subject public and the private sector".

The economy of the last 50 years was mainly based on agriculture, industry and finally on the development of tourism, intervening in increasingly significant ways on the transport system, infrastructures and urbanization processes and then on the exploitation of natural resources, forests and fisheries. This development has produced an impact on biodiversity and on the variety of landscapes in the country.

Prior to 1990, Albania had a centralized economic system that managed to maintain a relative balance between rural and urban people. After 1990, the liberalization of the economy produced a process of urbanization and migration from the countryside to the city of proportions never known before.

Movements of population from the countryside to the cities have led to a significant increase in the population centers in coastal urban with significant consequences on the environment. A number of animal species have begun to disappear, other have seen a dangerous decrease in their number; others are at risk of extinction.

Threats to the various natural ecosystems, especially forests and lagoon areas displace the local animal species by putting at risk the inherited natural balances.

As a potential candidate country for accession to the European Union, Albania has undertaken to combat environmental degradation. 
The promotion of Nature 2000 Network in Albania might help the Albanian Government to align its environmental legislation with that of the European Union, as well as to create development opportunities for the local communities who live in rural areas.

\section{Analysis of land use and relationship between coastline and infrastructure}

This section looks at the numerous processes involved in the evolution of land use caused by anthropic activities

In recent years the road networks, including roads and highways, has increased.

This new network has connect very distant areas within each country and replaced the local roads, that in Croatia followed the tortuous course of the coast and in Albania ran through the central part of the country, from North to South along the contours of the mountain territories.

Until 2000, the major Croatian infrastructures were built in the Northern part of the country in order to connect the coast with the capital Zagreb and the latter with the rest of Eastern Europe.

The motorway network, almost non-existent before 2000, is now completed in almost all the main directions.

The A1 Motorway, also called Dalmatinska Autocesta, which runs nearly parallel to the coastline, connects Zagreb with Sibenik, Split up to Ploče constituting an important artery for the development of the Croatian coastal area.

In the coming years the programmed completion up to Dubrovnik will become a main link for all of Croatia.

The project foresaw its completion within 2010 but so far this portion is not yet completed ending at Ploče, from which the zone of the Delta of Neretva can quickly be reached [16].

Even Albania has considerably increased its infrastructural heritage and in the period from 2005 to $2008789 \mathrm{~km}$ of new roads were made, $157 \mathrm{~km}$ of motorway and $1948 \mathrm{~km}$ of existing roads have been restored [17]. The Durrës-KukësMorine road, classified as Route no. 7 in the South-Eastern Europe network, was one of the priorities of the Albanian Government and it is $170 \mathrm{~km}$ long.

The reconstruction of the existing road that connects Durres and Tirana to the border with Macedonia (Corridor VIII) was completed, while two branches of this connecting Corridor are still under construction: the East-West part in the Region of Lushnje-Fier-Valona $(64 \mathrm{~km})$ and the Qafë Thane-Pogradec-Korçë segment $(63 \mathrm{~km})$.

Moreover, new ports are infrastructures that have changed the profile of the Croatian and Albanian coast. Croatia, really rich in islands, presents 56 marinas in service for recreational craft. The main ports are Zadar, Split and Dubrovnik, locations from which it is easy to reach the islands and the tourist coastal towns too.

The major seaports in Albania are Durres, Vlora, Saranda and Lezhe. Investment in maritime transport was mainly concentrated in the ports of Durres 
and Vlore, as main entrances of the Corridor VIII. Other territorial transformation of coastal areas is due to agriculture which occupies large flat areas of Croatia and Albania.

The lower course of the Neretva River (Figure 1) is a rare bio-ecological complex, as the result of centuries of natural modifications and more or less recent anthropic changes.

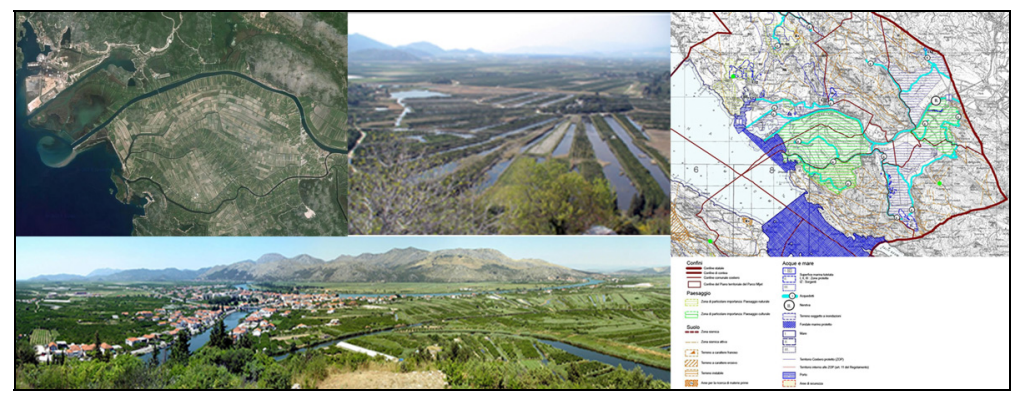

Figure 1: The landscape of the Neretva Delta (source: orthophotos 2014; photos Cialdea 2006; plan of Dubrovnik County - our elaboration).

The Neretva is the only river in the Region that opens into the sea with a delta mouth. At the same time the delta area presents the most intensive level of anthropic transformation.

If in the past, the alluvial plain was known for the malaria that systematically troubled the people, the improvements in the region over the last thirty years undertaken using FAO funds have much improved the general conditions of life in the region.

The Neretva river delta always attracts the attention of those who want to take advantage of its resources.

It is evident that the different morphological modifications, introduced by human activities in the delta area, are expression of the different cultures which in time survived.

However, the most significant transformation of this area appeared in recent decades, with a process of progressive reclamation aimed at protecting the region from flooding. An important aggression to the marshes was the drainage of the Modrič Lake and of the entire lagoon. This modification caused the destruction of the habitat of many species of seabirds and migratory birds that utilized this area.

The lower valley of the Neretva River is still at risk from the further expansion of the port and the urban area of Ploče, and vacation homes, industries and water pollution phenomena caused upstream by sewage from Mostar.

The lower valley of the Neretva River is also subject to agricultural exploitation, but water drainage is less intense than in the past. The agrarian landscape integrates however with the surrounding environment by providing the entire area a character strongly anthropized and for this it is different from the rest of the coast. The landscape of the Neretva delta is defined the Green Pearl of the Croatian Southern Coast. 
In Albania the Karavasta Lagoon (Figure 2) is located in the central part of the country and it extends for about 4,200 hectares. Today it is possible to observe the old dunes along the coast, rich in pine forests while the inland side is almost completely drained for agricultural purposes that is now inefficient and poorly preserved. Until 1991 the coastline was not very important for the economy. Industry and agricultural production were in fact the backbone of the economy. The area of Karavasta, with Lushnja as the capital of the District, was a distribution center, facilitated by the presence of the main road through the country connecting Tirana, Durres and Vlora. The economic importance of this area is demonstrated by the fact that many of the industrial plants (fertilizers, paper and glass) produced intermediate products, which are destined to many other districts.

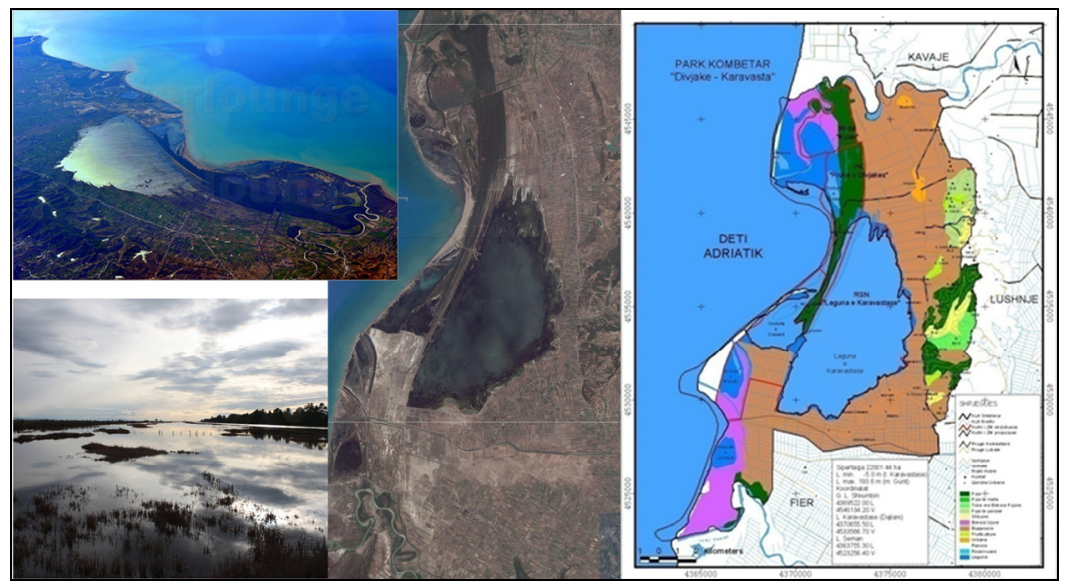

Figure 2: $\quad$ The landscape of the Karavasta Lagoon (source: orthophotos 2013; the park's plan of the Karavasta Lagoon - our elaboration).

After the 1991 political transformation, only a small part of the manufacture remained active, and heavy industry ended its activities. Lushnja and Fieri, both located along the most important road axis of the country, are among the most significant agricultural reality of the country, respectively with $61 \%$ and $72 \%$ of cultivated land.

The intense demand for lands in coastal plain began in the fifties, accompanied by the construction of a series of small settlements. Divjaka $(6,500$ inhabitants) and some other settlements (for a total population of approximately 10,000 inhabitants) were formed around the lagoon of Karavasta.

In the North-Eastern area of the lagoon, only the population of Divjaka and Niza has significantly increased in recent years. In this paper we present the analyses carried out on the site of the Neretva Delta and especially the analysis of the land use related to different types of protected zones in this area (Figure 3) and the analysis of agricultural use of the area set in the County Plan (Figure 4) In particular, Figure 3 shows the analysis of the land use, through the Corine Land Cover 2006 data. This area is not a real protected area, although the 
establishment of the Neretva Delta Park was already proposed in 2003 and then again in 2007. In our map protected areas are highlighted, as fish and bird reserves and protected landscapes. This area was also included in the Ramsar List in 1993, with an extension of 12,742 ha and, finally, it was classified as a Site of Community Importance and inserted in the European Nature 2000 Network and, as such, it is pending approval and, therefore, its Management Plan.

The area is therefore affected by various types of protection, lacking a total and organic safeguard in the area. Because of its environmental peculiarity, the Dubronik-Neretva County Plan [18] regulates its land use. Figure 4 shows, in fact, the requirements relating to the agricultural and forestry uses of the area under consideration, proposed by this Plan, combining the environmental and landscape safeguards for a correct and sustainable land use.

This area is of fundamental importance for agricultural production especially of fruit trees and citrus fruits. This production, which supplies all the national and international market, is abundant because inserted in those territories that were subject to the land reclamation projects in the $1950 \mathrm{~s}$.

\section{Conclusions}

The central aspect of this study is planning in coastal areas with particular regard to landscape protection. Indeed, the most critical elements of demographic and economic expansion converge on the coast.

In the last thirty years, the Italian case study, the Molise Region, has experienced intense construction activity, mainly concentrated in the eastern part of the regional coast that highlights the real hazard because of the consequences of urbanization.

A similar phenomenon certainly invests the Albanian coastal landscape, which, from the 1990s onwards, has been affected by the above-mentioned process of urbanization, mainly concentrated in the vicinity of more important urban areas, such as Durres and Valona.

This is occurring despite the fact that Croatia and Albania have very recent planning tools and laws closely linked to landscape protection policies. In fact, in Albania, after the new Parliamentary Democracy in 1991, there was a long transition period (1991-2000), during which the Government had serious difficulties in the management of cultural dynamics and policies, marked by strong internal contrasts.

The system planning framework in Albania began to be amended in 1998, in order to adapt it to the new political boundaries and the process of decentralization occurring in those years.

In order to halt the drastic changes in Albanian territorial exploitation, on 04.23.2009 the Albanian Government approved the Law no. 10119 on Land-Use Planning. It highlights the concept of sustainable development, together with the subsequent laws deriving from it.

Moreover, the final purpose of this law is not only to plan sustainable development but also to decentralize some planning powers. In fact, it transfers 

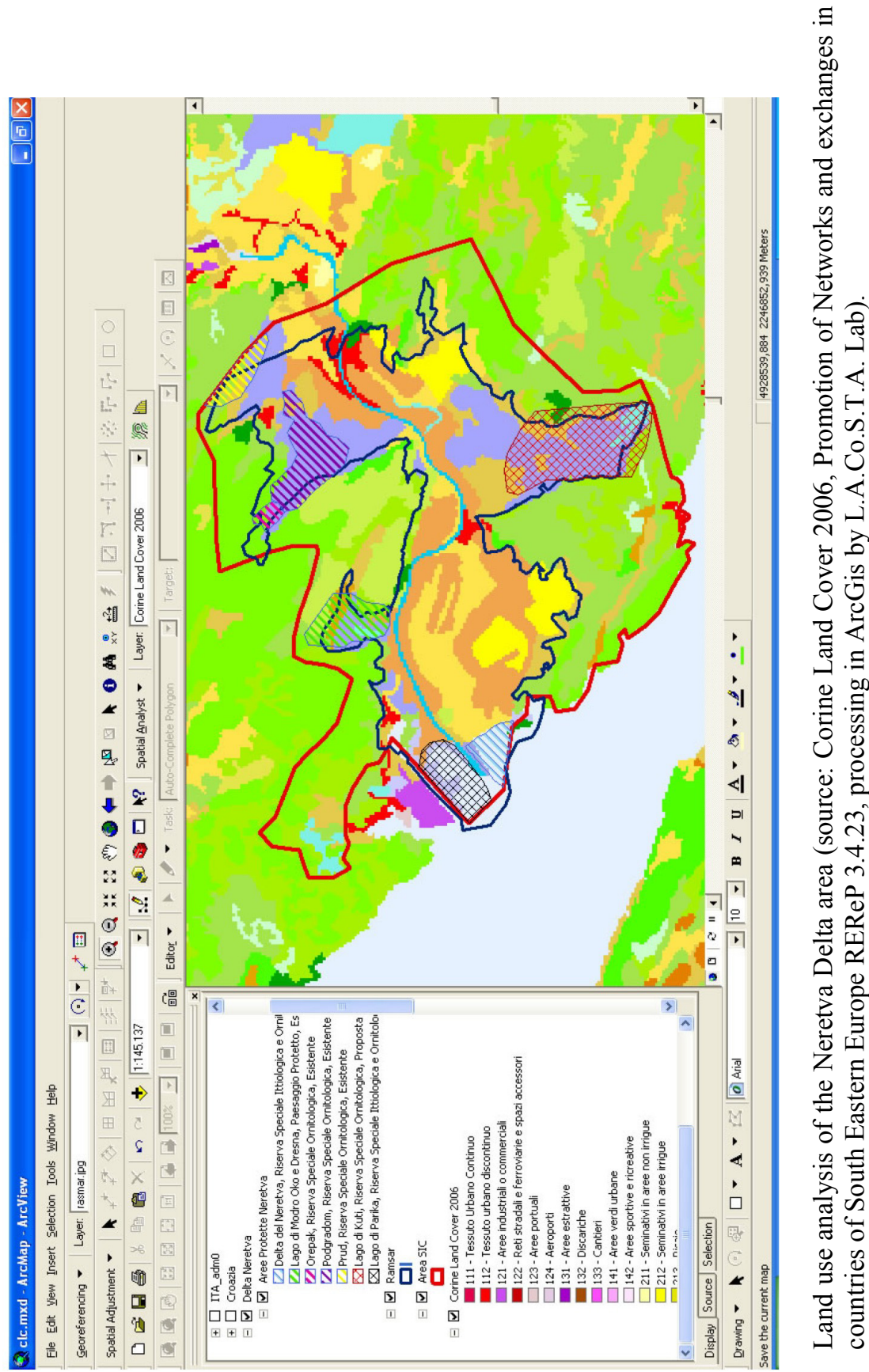

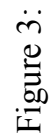




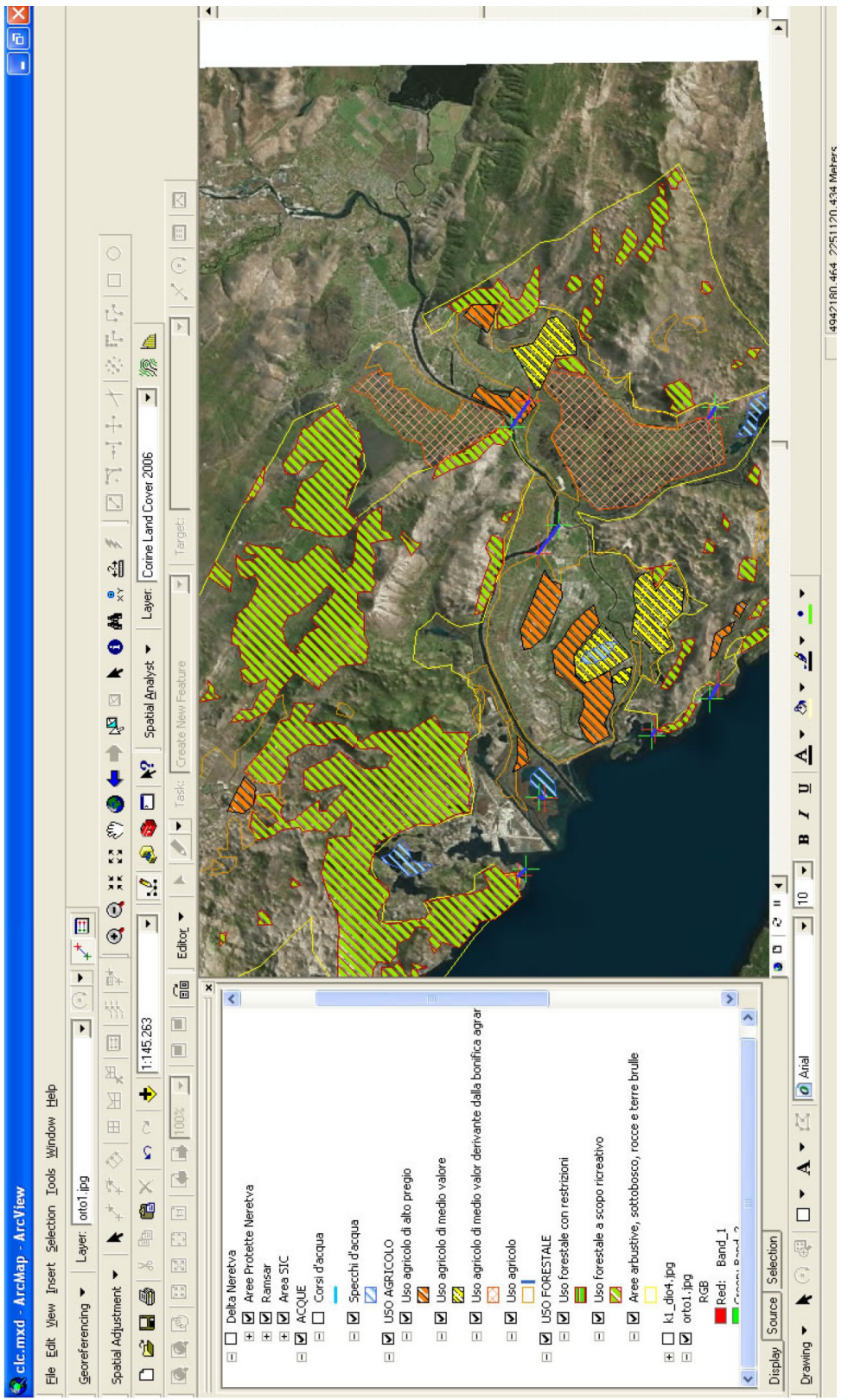


the decision-making process of urban planning from the Central Government to Local Authorities.

In Croatia, the law that provides guidelines for territorial planning was passed in 1994 [19]. Subsequently, the Spatial Planning Strategy providing guidelines for the protection of the land and for the quality of the environment came in to law in 1997. The development of the territory and its planning in Croatia was halted by the Civil War (1991-1996/98). Since 1998, enormous progress has been made in the field of spatial planning. Ten years later, the first generation of laws in planning matters has come in to being. The Law on Physical Planning and Construction was passed in 2007: it governs the system of urban planning and the construction sector.

This Government's attention for the coastal areas was a further reason that pushed our research towards examining the development of planning policy in Croatia.

To contain the uncontrolled urban development along the coastline, the Croatian Government passed Law no. 128/2005 that strengthens the protective measures for coastal heritage, extending the buffer zone and forcing Counties to update their planning instruments accordingly.

Moreover, the Dubrovnik-Neretva County Plan provides for the preservation and enhancement of cultural, natural, historical and environmental heritage, in addition to the conservation of marine resources.

This plan defines areas subject to protection and it intends to extend zones to enhance for tourism and where new constructions will be prevented, including derelict areas and uninhabited islands.

To conclude, each case study has highlighted the different approaches in these countries. Each has a diverse concept of the relationship between territorial planning issues and landscape planning tools. Moreover it is just as important to understand that the urbanization processes on the coast involve the inland territories, with their similarly fragile environmental and landscape contexts.

\section{References}

[1] Cialdea D., Research Methodology. Territorial Survey Interreg Reports. Materials for Adriatic Cross Border Project. Report No. 1. GES.S.TER. Project/Interreg IIIA vol. 1, pp. 1-88, Arti Grafiche La regione, Campobasso, 2005.

[2] Cialdea D. et al. Land Survey Materials. In: Cialdea D. Interreg Reports. Materials for Adriatic Cross Border Project Report No. 2 Land Use Evaluation. Analysis in the Different Landscape Performances GES.S.TER. Project/Interreg IIIA vol. 2 Chapter 4, pp. 173-177, Arti Grafiche La regione, Campobasso, 2006.

[3] Cialdea D. et al. The GIS Architecture Elements for the Coastal Areas along the Adriatic Sea. In: Proceedings of the Ersa 2006 in Volos Greece, 46th Congress of the European Regional Science Association, "Enlargement, Southern Europe \& the Mediterranean". Paper No. 348, Published on web wwwsre.wu-wien.ac.at /ERSA/ERSAC, 2006. 
[4] Cialdea D., Privitera S. The state of the environment on the Adriatic coast: elements of value and conflict, In: Proceedings of the 13th National Meeting of APDR University of Azores, Angra do Heroismo, Azores, Paper No. 241, Published on the web www.apdr.pt, 2007.

[5] Cialdea D. Definition of Landscape Quality Aims and Ongoing Research. In: Cialdea D. Interreg Reports. Materials for Adriatic Cross Border Project Report No. 3. Environmental Assessment GES.S.TER Project/ Interreg IIIA. vol. 3 Chapter 4, pp. 154-173, Arti Grafiche La regione, Campobasso, 2007.

[6] Cialdea D. The study of Adriatic coastal areas: valorisation hypothesis for sustainable development. In: Proceedings 13th National Meeting of APDR University of Azores, Angra do Heroismo, Azores, Portugal, Session 3 Sustainable development in Coastal Zones. Paper n. 240, Published on the web www.apdr.pt, 2007.

[7] De Stefani C., The two sides of the Adriatic Sea, Proceedings of the VIII Italian Geographical Congress, Florence, pp. 76-106, 1921.

[8] Almagiã, Who R., Sestini A., Trevisan L. (ed), Atlas of geographic types derived from the reliefs at 25000 and 50000 of the Military Geographic Institute, 2nd ed. rivedu-ta and expanded Florence, I.G.M., 1948.

[9] Lanzafame G., Tortorici L., geological Observations on the middle and lower basin of the Biferno River (Molise). Geol Roman, 1976.

[10] Go, I.P. (ed), Anatomy of an Orogen: The Apennines and adjacent Mediterranean Sponsored, Kluwer Academic Publishers, pp. 165-176, 2001.

[11] Vezzani L., Ghisetti F., Feast A., Geological Map of the Molise. 1:100,000, Florence, SELCA, 2004.

[12] European Commission, Implementare le Direttive Habitat e Uccelli in Croazia, in Natura2000 Notiziario natura e biodiversità, no. 34, pp. 623633, 2013.

[13] Dida, M. State of Forest Tree Genetic Resources in Albania. Forest Genetic Resources Working Papers, working Paper FGR/62E. Forest Resources Development Service, Forest Resources Division. FAO, Rome, 2003.

[14] Papayannis, T. and Pritchard, D.E., Cultures and Wetlands in the Mediterranean: an Evolving Story, Athens, Med-INA, 2011.

[15] Albanian Law for Protected Areas N. 8906, 06 June 2002.

[16] Glamuzina, B.; Glamuzina, M. Management of the Neretva River Estuary: Past and Future of a rich and fragile Natural Heritage, Naše Blackberries, no 46 vol. 5-6, pp. 226-230, 2001.

[17] AlbInvest - Albanian Business and Investment Agency - Tirana, Albanian Infrastructure Today, 2008.

[18] Conte Dubrovnik-Neretva, Prostorni plan Županije, Paper 1.3 Uvjeti Korištenja, Uređenja THE Zaštite Prostora Područja Posebnih Uvjeta Korištenja ztaništa (Izvor Park podataka Županijski Zavod za prostorno uređenje Dubrovnik).

[19] Law on Spatial Planning (1994), Official Gazette of the Republic of Croatia, No. 68/98. 